\title{
Entre Narciso e o colecionador ou o ponto cego do criador
}

Bento Prado Jr."

"Destinado a ver o iluminado, não a luz"

(Goethe)

Minha intenção, neste artigo, é sublinhar o liame (nem sempre visível na superfície dos textos ou no movimento nada linear que desenham) que une de maneira íntima o estilo do ensaio crítico de Gilda de Mello e Souza a seu sentido mais fundo: algo como uma "filosofia do sensível”, para utilizar a expressão de Merleau-Ponty ou como uma hermenêutica sem ecos teológico-metafísicos como a de um Gadamer ou de um Ricoeur ${ }^{1}$. Não é, com efeito, à primeira leitura que se revela a extraordinária eficácia interpretativa da démarche analítica de seus ensaios: é preciso todo o trabalho da reflexão para ver, no andamento caprichoso e sinuoso de sua escrita, que se demora amiúde em detalhes aparentemente pouco importantes, no alegre trânsito que efetua livremente, atravessando, em constante vai-e-vem, as fronteiras entre as artes (desde as menores às maiores: a moda, a dança, a fotografia, o cinema, a pintura, a arquitetura, o teatro, os diferentes gêneros literários, a música, essa "arte de pensar sem conceitos por meio de sons"2) algo mais do que o arbitrio de uma imaginação

* professor da Universidade Federal de São Carlos.

1 Sobretudo em Gadamer, tais ecos derivam da presença explícita, em sua concepção da hermenêutica, do segundo Heidegger, depois do Kehre, com sua revalorização do sagrado ou do mito, com seu retorno ao universo do romantismo alemão (origem, aliás, da moderna hermenêutica), com a filosofia de Schelling e a poesia de Hölderlin; Ricoeur, por sua vez, embora insista em marcar a separação entre as tarefas da filosofia e da teologia, não deixa, por isso mesmo, de reconhecer a consistência do projeto da teologia como que ao lado do projeto da filosofia. No que concerne a Gadamer (a despeito das restrições que faz à hermenêutica de Schleiermacher e a Schlegel, bem como ao historicismo e às Geisteswissenschaften da Alemanha dos oitocentos), guardemos apenas um argumento de 1943: "Na verdade, a razão não pode possibilitar a si própria. Ela própria é uma possibilidade e uma oportunidade históricas. Não compreende a si mesma e muito menos a realidade mitica que a abarca e sustenta" Cf. Gadamer, Georg Verdade e Método II, Ed. Vozes, 2a edição, col. Pensamento Humano, 2004, p.48 (página 36 do texto original).

2 Definição de Jules Combarieu (1859-1916) . Apud Souza, Gilda de Mello e A idéia e o figurado, Ed. Duas Cidades e Editora 34, Coleção espírito Crítico, São Paulo, 2005, p. 23. 
irresponsável ou um puro "impressionismo" que pouco cuidam da universalidade ${ }^{3}$. Para bem marcar meu ponto de partida, que me seja permitido recortar um trecho do último parágrafo de seu ensaio "O mestre de Apipucos e o turista aprendiz”, publicado em A idéia e o figurado, livro a que meu texto se limita quase que completamente. Ao termo de uma comparação entre as análises da obra de Cícero Dias por Mário de Andrade e Gilberto Freire, por ocasião das primeiras exposições do pintor na década de 20, Gilda retorna à experiência de sua geração na apropriação e no uso que fizeram das obras dos autores de Macunaíma e de Casa Grande e Senzala na fixação de seus próprios projetos intelectuais:

"Foi a partir deles [de Mário de Andrade e de Gilberto Freire] que a geração de moços, que entre 1935 e 1940, ainda não marcada pela especialização, começou a avaliar o conceito de cultura, de identidade nacional, a discutir com isenção o problema da mestiçagem e os rumos que a arte brasileira devia tomar. As conquistas obtidas eram em geral provisórias e não se apoiavam na segurança racional dos sistemas. Mas naquele momento de transição entre o sonho das vanguardas e a chegada vitoriosa dos especialistas, delineavam à nossa frente um recorte novo da realidade. Talvez uma invenção da realidade, tal como de tempos em tempos a arte efetua, para renovar o sentimento da divindade ${ }^{4}$, do homem ou, mais humildemente, da paisagem"

0 leitor não pode impedir-se de vislumbrar um mínimo de ambigüidade na contraposição que faz, neste texto, entre a "segurança racional dos sistemas" e as "conquistas [apenas], provisórias" que, no entanto, permitem a "invenção da realidade". De um lado, a autora parece descrever a passagem de sua geração à seguinte como um progresso, como

3 Antecipando observações ulteriores, não podemos deixar de notar, como índice da cumplicidade e da continuidade entre as obras de Mário de Andrade e de sua prima, no estilo como na temática, a maneira como Gilda descreve o estilo do autor de 0 Banquete: "Com o tempo os estudos mais aprofundados irão certamente unificar um pensamento caprichoso - 'em lascas', como ele chamou certa vez com humor - mas extremamente rico e pessoal; então, à semelhança da paisagem, que só transmite seu sentido verdadeiro quando a visão ordenadora do pintor a interpreta - nós o veremos se desenhar, finalmente, como um dos momentos mais altos da reflexão artística brasileira" Cf. A idéia e o figurado, p. 9.

4 Não podemos tomar essa expressão ao pé da letra. 0 "sentimento da divindade" não tem aqui qualquer significação religiosa ou mística: aponta antes para a utopia de uma sociedade e de uma cultura transparente, promessa de felicidade ("divindade" no sentido de Geist, em alemão, no sentido de Espírito Objetivo).

5 A idéia e o figurado, págs.69-70. 
aquele que levaria de conquistas apenas provisórias à solidez e à permanência garantidas pelo apoio racional em sistemas teóricos. Não é minha intenção, para reverter esse quadro, a de simplesmente retomar a retórica que fustiga o "esprit de système" com o elogio de um intuicionismo incontrolável (retórica contra a qual Pierre Bourdieu dispara, em seu texto sobre Erwin Panofsky ${ }^{6}$, as setas envenenadas da retórica do estruturalismo, como veremos adiante). Parece importante sugerir que a mutação aludida também é uma forma de empobrecimento da visão ( a perda do saper vedere e, por que não?, do saper leggere e sentire, ascoltare) que acompanha a institucionalização do saber especializado, que despreza os processos heurísticos ou abductivos, no limite hermenêuticos, da decifração da vida da cultura (reiterando idéias de Adorno ${ }^{7}$, como veremos logo a seguir). Pelo menos, é nessa mesma direção que caminha Otília Beatriz Fiori Arantes em seu ainda inédito ensaio "Notas sobre o método crítico de Gilda de Mello e Souza”, publicado a seguir, pp 37-49, falando de um "milagre acadêmico" realizado há meio século ${ }^{8}$ e que hoje nos parece fora de alcance ou acima de nossas forças. Milagre acadêmico ou proeza cognitiva possibilitados por um uso original de métodos desprezados na Academia como o método indiciário, essencialmente abductivo ou heurístico, pouco compatível com a linha dura epistemológica imperante na Universidade ${ }^{9}$. Não posso discordar do diagnóstico feito por Otília: tendo feito meu curso na USP na segunda metade da década de 50, não podia con-

6 No posfácio à sua tradução do livro de Panofsky Architecture gothique et pensée scolastique, Les Éditions de Minuit, Collection Le Sens Commun, 1986.

7 Foi, de fato, com entusiasmo que descobri, nos anos 60, graças a Roberto Schwarz, nas Notas de literatura de Adorno (publicado em 1958), o belo texto "0 ensaio como forma" (do qual roubei a epígrafe deste escrito) que se abre levantando-se contra a desqualificação contemporânea desse gênero literário. 0 que ocorria no nosso longínquo Brasil, ocorria também na culta Alemanha. Como diz Adorno: "Que o ensaio, na Alemanha, esteja difamado como um produto bastardo; que sua forma careça de uma tradição convincente; que suas demandas enfáticas só tenham sido satisfeitas de modo intermitente, tudo isso já foi dito e repreendido bastante."(Cf. Notas de Literatura I, tradução e apresentação de Jorge de Almeida, Ed. Duas Cidades e Editora 34, 2003, Coleção espírito Crítico, p.15).

8 Trata-se da tese de doutoramento A Moda no século XIX, defendida em 1950 e publicada originalmente pela Revista do Museu Paulista, só publicada em forma de livro em 1987, sob o título de O Espirito das Roupas, pela Cia. Das Letras.

9 Otília sublinha, no já referido ensaio, o entusiasmo com que Gilda leu o livro de Carlo Ginzburg Mitos, emblemas, sinais, que confirmava suas preferências metodológicas, valorizando tanto "a arqueologia visual dos mestres da escola de Warburg" quanto o "método indiciário", especialmente o praticado por Giovanni Morelli no século XIX. 
cordar com o que me parecia uma injustificável desqualificação (de espírito no fundo "cientificista", com o privilégio concedido sobretudo à epistemologia), do ensaísmo entendido como um gênero já superado no âmbito da "séria" pesquisa universitária. Ensaísmo? - coisa de amador! A contrapelo dessa tendência dominante, ficávamos deslumbrados com o estilo ensaístico ou com a forma de pesquisa e ensino de nossa professora de Estética que, em lugar de expor "teorias estéticas", preferia analisar este quadro, este poema, este filme, ensinando-nos a "ver" como diz Merleau-Ponty, numa frase que Gilda colheu em Le visible et l'invisible para servir de epígrafe de seu ensaio "Variações sobre Michelangelo Antonioni".

Através da interpretação do estilo da escrita de Gilda de Mello e Souza, o que visamos em última instância é o próprio conteúdo de seu pensamento ou o alcance propriamente filosófico de sua obra, que a autora deixa discreta ou modestamente à sombra. Um pensamento que é capaz de passar entre Caríbdis e Scila, ou seja, nos termos de Adorno, entre a "ciência organizada" (no interior da "cultura administrada") e uma filosofia que se contenta com o "resto vazio e abstrato", sem recorrer às vias opostas do intelectualismo e do empirismo ou ainda à via fácil do mero impressionismo. Nem formalismo, nem intuicionismo, mas um procedimento metódico que não denega a ambigüidade ou as contradições da experiência, desentranhando, ao contrário, os pontos cegos que a impregnam, permitindo uma lucidez maior, uma visão mais clara do mundo que nos cerca e da cultura que nos formou. "Aprender a ver" como já vimos na frase de Merleau-Ponty, segundo um procedimento bem descrito por outro filósofo que não tem afinidade alguma com a tradição da fenomenologia; falo de Michel Foucault que dizia, numa conferência pronunciada no Japão em abril de 1978: "Há muito que sabemos que o papel da filosofia não é o de descobrir o que está escondido, mas de tornar visivel o que é precisamente visivel, isto é, de fazer aparecer o que está próximo, o que é imediato, o que está tão intimamente ligado a nós e, por isso, não percebemos. Enquanto o papel da ciência é o de fazer conhecer o que não vemos, o papel da filosofia é o de tornar visivel o que vemos"10.

10 Frase anotada por Arnold Davidson e citada por Christiane Chauviré em seu livro Voir l'invisible: la seconde philosophie de Wittgenstein, PUF, Coll. Philosophies, 2003, p. 9. É oportuno lembrar que, a despeito das diferenças que separam filósofos como Husserl, Heidegger e Wittgenstein, encontramos sob suas penas frases com um conteúdo exatamente igual às enunciadas aqui por Foucault. Por exemplo, Heidegger afirma, em algum lugar, que não vemos nossos óculos por que estão próximos demais; por sua vez, Wittgenstein afirma: "Deus garante ao filósofo a intuição do que está diante dos olhos de todo mundo." 
Para percorrer essa conexão entre a hermenêutica e seus resultados teóricos, deter-me-ei no livro A Ideía e o Figurado, especialmente nos textos consagrados a Mário de Andrade, no espaço periférico que habitamos, e a Michelangelo Antonioni, no coração da cultura européia; só sairemos do referido livro passando brevemente pela entrevista que Gilda concedeu a respeito do filme Conversation piece de Visconti.

II

Os ensaios consagrados a Mario de Andrade percorrem muitas linhas ou níveis que - tarefa complexa! - é preciso tentar desentranhar; esperamos que após esta tentativa, "com o tempo os estudos mais aprofundados irão certamente unificar um pensamento caprichoso", como diz a própria Gilda na frase acima citada sobre o autor de $\mathrm{O}$ Banquete. Com efeito, em seus escritos sobre ele, Gilda de Mello e Souza examina as teorias estéticas, os textos programáticos, a obra poética, o trabalho do colecionador de obras de arte, o teórico da cultura brasileira, sempre sobre o fundo da familiaridade com o itinerário biográfico de seu primo, que atravessou diversos dilemas, crises e conflitos interiores. A complexidade dessas múltiplas linhas analíticas que se cruzam multiplica-se muito com a grande afinidade entre a autora e Mário de Andrade no que concerne ao estilo do trabalho crítico e das perspectivas da reflexão estética.

Assim, no ensaio "0 professor de música”, ao expor esquematicamente a estética de Mário de Andrade, tudo parece levar-nos a crer que, até certo ponto, a autora faz suas as teses expostas, como tentaremos mostrar ao longo deste escrito. Vejamos como é definida a estrutura da manifestação musical segundo Mário de Andrade nas palavras de Gilda: "São quatro as entidades que compõem a manifestação musical: o criador, a obra-de-arte, o intérprete e o ou$v_{\text {vinte" }}{ }^{11}$. Uma vez exposta essa estrutura de quatro termos, Gilda insiste no fato de Mário de Andrade militar especificamente contra o privilégio atribuído ao criador, especialmente na tradição romântica do gênio criador em contacto imediato com o Absoluto (pensemos no Heinrich von Ofterdingen de Novalis que, a contrapelo do Wilhelm Meister de Goethe, com tudo o que implicava de concessão ao realismo, faz a totalidade do Mundo - inclusive o leitor do livro... - ser absorvida pela imaginação produtiva do poeta). À divinização do criador opõe-se a ênfase nos demais termos: a obra, o intérprete e o ouvinte. Não só a obra está "acima" do criador que só nela pode esperar atingir sua "integridade

11 A idéia e o figurado, p. 24. 
vital no domínio do espirito", como a própria obra só se realiza na audição ou com sua recepção pelo ouvinte através da mediação essencial do intérprete, mesmo se ela não é passivamente fiel, mesmo se ela é relativamente traidora. Algo como uma antecipação da "estética da recepção", hoje tão em moda entre nós? Pelo menos levemente diferente de Jauss $^{12}$, Mário de Andrade liga o privilégio da recepção a algo como uma essencial alienação do criador, que precede e enriquece o processo global criação/recepção. Uma alienação que lhe impede o domínio total do sentido de sua própria obra: só o outro pode dizer minha verdade. Aqui a psicanálise (e a dialética, como veremos) não é colocada fora de jogo.

Detenhamo-nos um instante nesta idéia e aceitemos o risco de ousar, nós mesmos, uma hipótese sobre a relação Mário de Andrade/Gilda de Mello e Souza. Tivemos, com efeito, a impressão de que nos seus escritos sobre Mário de Andrade, Gilda parece sugerir algo como uma descontinuidade entre a Estética e a Poética do autor em tela (utilizando a distinção metodológica de Luigi Pareyson ${ }^{13}$ ). De um lado, uma Estética que descreve, de um ponto de vista contemplativo, a curva feliz da obra, em seu percurso do criador ao ouvinte através da mediação do intérprete, que culmina numa transparência total: "Em resumo, o intérprete ideal - como o ouvinte ideal - seria para Mário de Andrade o puramente receptivo, aquele que 'disposto a amar' soubesse se despojar dos idolos de toda espécie, das verdades transitórias, dos preconceitos adquiridos através dos anos, da veneração descabida, para se nortear, sobretudo, pela compreensão exata do passado"14. De outro, uma Poética - essencialmente um projeto, uma escolha da forma e do sentido da obra a ser criada - que, desde o início do itinerário de Mário de Andrade até seu ponto final, se elabora na sucessão de crises, de conflitos e contradições, de alternativas inconciliáveis, que são freqüentemente interpretados pelo próprio autor como uma doença, como uma insuperável e trágica divisão do Eu ou da personalidade.

12 Com efeito, em Experiência Estética e Hermenêutica Literária (1977) Jauss parece devolver à criação parte do espaço que concedera à recepção.

13 Ibidem., p. 10 “...esboçando o que se poderia chamar - de acordo com a esclarecedora distinção metodológica de Pareyson - uma Poética e uma Estética propriamente. Isto é, teríamos, de um lado, uma doutrina 'programática e operativa', ligada a um momento determinado da história, que tenta traduzir em normas um programa definido de arte (Poética); de outro, uma reflexão desinteressada de caráter filosófico e especulativo (Estética)".

14 Ibidem, p. 26. 
Assim, no texto "0 professor de música", buscando situar historicamente o compêndio sobre Estética Musical ${ }^{15}$, Gilda desenha o duplo itinerário de Mário de Andrade de 1922 a 1928 (esboço que será refinado de perspectivas diferentes e de crescente complexidade nos ensaios seguintes) E, para fazê-lo, começa com uma obra-prima de iconologia (ainda uma vez, saper vedere!) tão brilhante que nada deixa a desejar em relação às análises de obras pictóricas como, por exemplo, as de João Câmara Filho, Gregório Gruber e Rita Loureiro: trata-se de um estudo comparativo de duas fotografias e de duas posturas de Mário de Andrade - na fotografia dos professores do Conservatório Dramático e Musical de São Paulo e na do almoço comemorativo da Semana de 22. Digamos: dois horizontes (ou duas "situações", dois "mundos") opostos, onde se mostram duas faces de Mário de Andrade, cada uma figurando o ponto de partida de uma das duas jornadas divergentes que se iniciam: "A primeira fotografia fixa os professores do Conservatório no almoço em que comemoram a promoção do companheiro mais jovem. A imagem é convencional e respeitosa, desde a colocação dos figurantes, que se distribuem de acordo com a idade e o merecimento"16. Na outra fotografia os modernistas mostram-se espontâneos e à vontade: "A distribuição dos retratados é casual, não se sente nenhuma preocupação de pose na atitude dos corpos"17. No contra-ponto entre essas fotografias, a análise desentranha dois códigos opostos, duas formas diferentes do habitus (para retomar a expressão que Panofsky tomou da escolástica) que filtram, cada uma à sua maneira, o socius e o cosmo, ao mesmo tempo em que exprimem, segundo o mesmo paradigma, a própria subjetividade. São pormenores puramente formais (modelos de roupas, suas combinações do claro e do escuro) que permitem dar a ver a diferença entre esses dois modos de ser-com-outrem e de exprimir-se: a disposição dos figurantes (ordenados segundo uma hierarquia ou livremente agrupados), a cor e o corte das vestes (todos de preto, no mesmo estilo, ou diferentes estilos, cores, tecidos: da lã mesclada ao veludo cinzento, etc...), a postura corporal (posição vertical "à espera de servir" ou liberdade e variedade postural, espontaneidade das mãos que se posicionam diversamente, sem constrangimento) etc...

A presença de Mário de Andrade nos dois grupos revela a cisão presente no início de sua carreira a partir da

15 Andrade, Mário de Introdução à estética musical, org. por Flávia Camargo Toni, São Paulo, Hucitec, 1995.

16 A idéia e o figurado, p. 14.

17 Ibidem, p. 16. 
qual Gilda acompanha, nos anos que se seguem, a conciliação provisória (mas sempre em crise) exposta na sua Introdução à estética musical. Nossa autora descreve essa evolução de 22 a 28: o télos da reconciliação está presente desde o início, antes do esforço de reflexão (com a ajuda da fenomenologia e da psicanálise, que introduzem, ao convergirem, um resíduo aparentemente ineliminável de tensão ${ }^{18}$ ) que se exprime numa teoria da arte como "sublimação de um ato de amor" - reconciliação consigo mesmo graças a uma dádiva a outrem.

Mas essa reconciliação pensada na Estética não é $v i$ vida concretamente na prática da Poética e no itinerário biográfico. De resto a Estética, por mais sublime que fosse seu "elemento", dava lugar à precariedade do criador (uma espécie de infelicidade ou de inferioridade) que Mário de Andrade descobre dolorosamente como seu próprio destino pessoal. Como exemplifica o trecho citado da carta a Oneyda Alvarenga quase ao termo de "O professor de música": "Eu sou um ser como que dotado de duas vidas simultâneas, como seres dotados de dois estômagos. $O$ que mais me estranha é que não há consecutividade nessas duas vidas -o que seria mais ou menos comum [...]. Há completa disparidade, uma sofrida e a outra incapaz de qualquer espécie de dor [...]. A verdade é que são vidas díspares, que não buscam entre si a menor espécie de harmonia, incapazes de se amelhorarem uma pelo auxilio da outra"19. Há que sublinhar que essa divisão ou alienação existencial exprime também as contradições enfrentadas na empresa da Poética. É a “crise do nacionalismo", (cuja análise será retomada mais agudamente por Gilda nos ensaios subseqüentes - "A poesia de Mário de Andrade", "0 colecionador e sua coleção" e "0 mestre de Apipucos e o turista aprendiz" - e que aqui se mostra como a passagem do "exteriorismo representativo" da primeira fase à fase "artífice", "invisível”, de Louvação da Tarde), é essa crise, repitamos, que se exprime em toda a sua violência na carta endereçada a Carlos Drummond de Andrade em 28 de fevereiro de 1928: "Pois esse tal de brasileirismo está me fatigando um bocado, de tão repetido e tão aparente. 'Sou brasileiro' é frase que me horroriza, palavra [...] Também publico o Macunaima que já está feito e não

18 Embora seja evidente o conflito entre a fenomenologia de Husserl e a teoria de Freud, em seus ensaios Gilda pode combiná-las graças à ponte construída entre elas na década de 20 (com Biswanger, Minkowski entre outros) e esboçar uma espécie de "psicanálise existencial" com a ajuda da fenomenologia do imaginário de Gaston Bachelard, onde é visível a marca da versão jungiana da psicanálise.

19 Ibidem, p. 25. 
quero mais saber de brasileirismo de estandarte [...] Meu espirito é que é por demais livre para acreditar no estandarte. E por ai você já vai percebendo quanto me sacrifico em mim pela arte de ação que me dou, que me interessa mais, tem maior função humana e vale mais do que eu. Mas agora a ação já está feita e o que carece é a contra-ação porque o pessoal engoliu a pílula e foi na onda com cegueira de carneirada. Confesso que quando me pus a trabalhar pró-brasilidade complexa e integral (coisa que não se resume como tantos imaginaram no trabalho da linguagem) confesso que nunca supus a vitória tão fácil e o ritmo tão pegável. Pegou. Eu estou disposto a dedicar minha vida pro trabalho. Bastaram uns poucos anos. Tanto melhor: vamos pra frente!" ${ }^{20}$.

Nesta carta, paradoxalmente, o êxito da iniciativa revolucionária dos modernistas é descrita quase como uma deсерção (foi tão fácil!). Mas, sobretudo, aponta para uma nova fase, para a passagem da ação para a contra-ação. Que significa tal virada? Na gênese da Poética, significa a passagem a um novo estilo de poesia, mais elevado e meditativo, que culminaria na extraordinária "Meditação sobre o Tietê" escrito às vésperas da morte. Estilo meditativo já que se exprime, por exemplo, no poema "Louvação da Tarde": "Este último caso é o da "Louvação da Tarde", onde aparece um traço importante de Mário de Andrade: a realização do novo pela fidelidade à tradição. Lendo esses admiráveis decassilabos brancos, pensamos quase insensivelmente em alguns de nossos poetas do passado e nos poetas ingleses 'dos lagos', sobretudo Wordsworth, aos quais Mário se refere implicitamente na simples adoção desse tipo de poema"21. Acrescentemos que aí temos apenas uma das vertentes da nova fase que se manifesta tanto no "devaneio do caminho" como no "devaneio do repouso", nas expressões que Gilda de Mello e Souza toma de empréstimo a Gaston Bachelard. Ou na combinação dos dois devaneios no poema que exprime a passagem do movimento vertiginoso à paz da imobilidade estática, do repouso final ou da paz absoluta, como aquela que se exprimia na experiência do intérprete e do ouvinte ideais da música, que parece transcender todo tipo de conflito ou de inquietação, na comunicação e na transparência totais.

Aparentemente o devaneio do repouso não atinge essa transparência final e a redenção musical parece estar além do alcance da poética. É o que talvez se mostre tanto no poema "Noturno de Belo Horizonte" como no "apólogo" do "moço comido de maleita" de $O$ turista aprendiz. A paz final a ser atingida não seria uma forma de doença, no entregar-

20 Ibidem, p. 18-9.

21 Ibidem, p. 30. 
se à maleita e à preguiça? Demoremo-nos na análise que Gilda faz do poema, em especial do seguinte trecho:

"Desgarram serra abaixo.

Rio das Mortes

Paraopeba

Paraibuna,

Mamotes brancos...

E o Araçui de Fernão Dias...

Barafustam vargens fora

Até acalmarem muito longe exânimes

Nas polidas lagoas de cabeça pra baixo."

Em seu comentário, Gilda situa o trecho dentro da estrutura do poema: em seu início, o poeta percorre o universo "sombrio" de Belo Horizonte, mas logo se volta para a "paisagem agreste das Gerais", onde divisa o movimento tumultuoso dos rios, que não deixa de espelhar a tempestade de sua vida interior. Mas, o devaneio do caminho (da abertura de caminhos como a que a torrente d'água cava na terra, nela talhando seu leito ou daquela outra abertura imposta pelo poeta à tradição literária) não suprime o devaneio do repouso. No rio espelha-se o movimento impetuoso da vida interior do criador que aspira a encontrar, ao termo de seu itinerário, a reconciliação da expressão artística que se torna feliz e tranqüila como as águas que repousam " $f i$ nalmente nas lagoas". Curiosamente, como na Fenomenologia do Espírito de $\mathrm{Hegel}^{22}$ a consciência perceptiva que se torna entendimento (passando da coisa à lei ou à força, mesmo antes do advento da consciência de si e da consciência infeliz) começa a ver diante de si o mundo invertido (Verkehrte Welt), aqui também o poeta, que passa do movimento tempestuoso da alma à serena criação/contemplação, acaba por vislumbrar sua própria fisionomia invertida. A subjetividade dividida não se transcende e permanece presa da relação "conflituosa" consigo mesma (em termos hegelianos, não se reencontra no Universal da Arte ou do Espírito) como índice trágico da insuperável contradição. Tal pa-

22 Não será abusiva esta referência a Hegel? Lembremos que, comentando a passagem da percepção ao entendimento e à idéia de mundo invertido, Jean Hyppolyte, em seu livro Genèse et structure de la Phénomenologie de l'Esprit de Hegel (Ed. Aubier, 1946, p. 133), ao examinar a dimensão físico-científica dessa passagem (a ligação interna entre os pólos opostos do oxigênio e do hidrogênio), aponta para o sentido espiritual dessa dialética, especialmente a dialética crime/castigo. 0 que lhe permite acrescentar: "Pensamos no livro célebre de Dostoievsky e não é a única vez em que a dialética hegeliana sugere as intuições que o romancista russo desenvolverá mais tarde". Não é impossivel passar da filosofia especulativa para a literatura. 
rece ser a conclusão de Gilda: "Mas a meu ver, a chave desse trecho misterioso cuja compreensão exige não só uma leitura alternativa, mas um conhecimento da biografia intelectual de Mário de Andrade, está na imagem do último verso. Pois não são as águas polidas, onde os rios vêm desaguar, já sem forças, que estão de cabeça para baixo, é o poeta que, postado à sua margem, cansado da travessia, inseguro, assim divisa a própria imagem, debruçando-se sobre as águas onde busca um valor, uma certeza"23

Trata-se da encarnação de Narciso, mas de um Narciso incapaz de enunciar, como o de Ovídio, "Iste ego sum! sensi; nec me mea fallit imago" ${ }^{4}$, já que só é capaz de neutralizar sua própria imagem por uma espécie de adormecimento ou de embriaguez. Com o abismo entre eu e sua imagem, o para-si e o para-outrem, permanece a "bi-vitalidade" de que fala Gilda e de que o poeta só pode tentar desfazer-se através da fuga, da viagem ou do muro de obras de que se cerca como colecionador. A viagem, em primeiro lugar, originariamente iniciada como busca da redescoberta do Brasil e de si mesmo como ser unitário, parece só culminar na reunificação graças à redução da existência ao nível inferior do "êxtase da sensibilidade"... É o que parece estar expresso em carta a Manuel Bandeira, da qual Gilda cita o seguinte trecho: "O êxtase vai me abatendo cada vez mais. Me entreguei com uma volúpia que nunca possui à contemplação destas coisas, e não tenho por isso o minimo controle sobre mim mesmo. A inteligência não há meios de reagir nem aquele poucadinho necessário pra realizar em dados ou em bases de consciência o que os sentidos vão recebendo. Estou ganzlich [completamente] animalizado"25. Um êxtase em que a imagem invertida do próprio rosto ou a divisão entre o eu e o contra-eu parece dissolver-se não numa unidade superior, mas como uma espécie de queda ou de doença. Como diz literalmente Mário de Andrade em crônica citada por Gilda: "Assim a obsessão de minha vida, não é o acesso de febre. Nem no acesso de febre se resume a filosofia da maleita [nós sublinhamos, - B. P. Jr.], com o perdão da palavra. Está claro que o meu desejo é mais elevado. Quero, desejo ardentemente é ser maleitoso não aqui, com trabalhos a fazer, com a última revista, o próximo jogo de futebol, o próximo livro a terminar. Desejo a doença com todo o seu ambiente e expressão, num igarapé do Madeira com seus ja-

23 A idéia e o figurado, p. 39-40.

24 0vídio, As Metamorfoses, livro III, 463 "Esse sou eu! percebo; já não me engana mais a minha imagem".

25 A idéia e o figurado, p. 59. 
carés, ou na praia de Tambaú com seus coqueiros, no silêncio, rodeado de deuses, de perguntas, de paciências. Com trabalhos episódicos e desdatados, ou duma vez sem trabalho nenhum. Quanto ao sofrimento dos acessos periódicos, não é isso que desejo, mas a prostração posterior, o aniquilamento assombrado, cheio de medos sem covardia, a indiferença, a semi-morte igualitária" 26

Não é arbitrariamente (ou por vontade de injetar artificialmente a filosofia especulativa no livre andamento do ensaio de Gilda de Mello e Souza) que ligo, como que por uma dialética descendente, o tema do "mundo invertido" ao da "filosofia da maleita", em contraposição com a dialética hegeliana que leva do Verkehrte Welt (Mundo Invertido) à Anerkennung (Reconhecimento) mediante a passagem da consciência infeliz ou dividida a uma forma feliz e transparente da sociabilidade. A própria Gilda faz essa ligação ao comentar a "monografia humorística" da tribo amazônica dos Do-Mi-Sol: "À semelhança dos estratagemas óticos, postos em voga pela psicologia-da-forma - em que num desenho intrincado podemos ler, indiferentemente, a figura como fundo e o fundo como figura - Mário nos força através deste exemplo [da tribo que inverte as funções da linguagem articulada e da música - nota de B.P.Jr.] a apreender um traço que supúnhamos natural, como aberrante, e uma aberração como um simples traço cultural. Assim, o mundo de cabeça-para-baixo que nos é descrito aqui antecipa e reforça, como veremos a seguir, o episódio do maleitoso, que irá encerrar a viagem e a longa meditação sobre o Brasil"27.

Mas a "filosofia da maleita" não leva apenas o criador em crise à tentação do repouso inerte "sem trabalho algum". Para além dessa tentação, agita-o outro impulso que também o leva para longe de si mesmo. Na mesma viagem em que descobre o prazer da "animalização" ou da pura aisthesis desacompanhada do trabalho da reflexão, descobre a via redentora do voyeur colecionador, voltado integralmente para fora de si: "Sabe que para apreender a realidade é preciso continuar se afastando de si mesmo, das lembranças pessoais, do presente, para penetrar na zona adormecida em que 'vestígios inertes', 'congelados', 'parecem emergir do curso do tempo': modismos, ditos e quadros populares, frases feitas, melodias esquecidas, destroços de danças dramáticas, ruínas de arquitetura, imagens se desfazendo. Grafa. Fotografa. Re-

26 Ibidem, p. 67.

27 Ibidem, p. 65. 
gistra. Ficha. Recolhe." ${ }^{28}$ A figura de Narciso é substituída pela do colecionador, cuja coleção garante uma decifração do outro, uma mais fina representação do Brasil e, ao mesmo tempo, um muro protetor em torno da subjetividade incerta de si mesma. De retorno da viagem, Narciso pode finalmente repousar: "está ali, bem protegido, o mundo de que necessita: dócil, ordenado, ao alcance da mão e do olhar. Já não é preciso travar a cada passo o duro corpo-a-corpo com as coisas, com o outro, com o real; agora basta ficar atento aos sinais e desentranhar das formas, das estruturas, as complexas relações de significação. Pois não acumulou visando o lucro, como um marchand, ou status, como um novo rico, mas para chegar mais perto do Homem e do mundo. Para que um dia, olhando a coleção, ele se reconhecesse, pudesse refazer o grande puzzle de sua vida, de sua época. O colecionador descansa na coleção". Mas essa reconciliação final não é completa e não elimina (voltando à teoria das quatro instâncias da Estética de que partimos) a precariedade do criador e a ilusão da docilidade e do caráter ordenado das formas. 0 rosto do criador e a "autonomia incontrolável das formas" 29 só podem revelar seu segredo para nós, espectadores ou leitores, de qualquer modo o último termo onde se realiza plenamente a obra de arte. É o que parece sugerir a bela conclusão que Gilda de Mello e Souza dá a seu ensaio "O colecionador e sua coleção": "Fechado no mundo que criou, feito à sua imagem e semelhança, ele continuará se interrogando; é de seu feitio interrogar-se. Deixemos, pois, que Narciso contemple desencantado a própria imagem. Indiferente ao aceno persistente de seu gesto, desviemos dele nosso olhar, para ir descobrindo à nossa volta, no que recolheu com paciência e semeou com paixão, o rosto verdadeiro que ele não soube, ou não ousou divisar".

III

Depois de acompanhar a linha sinuosa pela qual Gilda de Mello e Souza percorre os diversos níveis da obra literária e teórico-crítica de Mário de Andrade, talvez seja útil aproximarmo-nos mais de seu estilo e do núcleo de seu pensamento, com o contraponto entre os ensaios consagrados ao autor de Macunaima e sua análise do cinema italiano, especialmente em seu ensaio "Variações sobre Michelangelo Antonioni”. É essencial, como disse no início deste texto, o que

28 Ibidem, p. 43.

29 Expressão do final do ensaio sobre Antonioni, que mostra a ligação subterrânea entre os textos consagrados a Mário de Andrade e o ensaio "Variações sobre Michelangelo Antonioni" de que cuidaremos a seguir. 
há de revelador nesse estilo singular que transita, com agilidade e felicidade, através dos limites entre as diferentes formas de arte, fixando constantes ou universais da criação artística. Lembrando Mário de Andrade: "Não se ensina Música, se ensina Arte". Com o que começamos a passar da crítica de arte para a Estética e para a Filosofia, tentando atingir nosso alvo último.

Mas, antes de entrar no comentário do ensaio sobre Antonioni, que me seja permitido sair, por um breve instante, do âmbito de A idéia e o figurado, para buscar um elo extremamente útil, para nossa análise, na entrevista que Gilda de Mello e Souza concedeu a Carlos Augusto Calil a propósito do filme Conversation piece do Conde Luchino Visconti ${ }^{30}$. Por quê? Porque o protagonista interpretado por Burt Lancaster reúne elementos presentes na vida e na obra de Mário de Andrade: a condição da consciência infeliz do intelectual que se preserva do mundo e de si mesmo na condição de colecionador e de connaisseur (personagem que, por outro lado, permite a transição para o fotógrafo Thomas, central no filme Blow-up).

Antes, todavia, de fazer o contraponto, sublinhemos as distâncias que separam os pólos que pretendemos ligar, no mesmo ato em que os opomos. De fato, ao passar de Mário de Andrade ao cinema italiano, passamos da poesia e da crítica de arte brasileira da primeira metade do século XX ao cinema de vanguarda da Itália da segunda metade do século (o filme de Antonioni é de 1966 e o de Visconti de 1974). Além do mais, nesse contraponto, passamos da periferia da cultura européia para o seu centro e de uma obra que visa, no Brasil em formação, a cultura do futuro a ser criada, a duas obras que descrevem a dissolução de uma cultura passada, numa época em que já se esboçava a figura catastrófica do mundo que nos é contemporâneo. De qualquer maneira, sem qualquer menção a Mário de Andrade, (a conexão é de nossa única e exclusiva responsabilidade), Gilda nos faz ver, no filme de Visconti, a mesma figura do colecionador que neutraliza a dolorosa divisão de sua consciência (entre o passado a ser preservado de algum modo e o mundo presente que rejeita), na solidão e na intimidade de sua suntuosa residência de janelas fechadas, reconciliando-se consigo mesmo na contemplação da pintura inglesa ( a Conversation piece é justamente a representação do nobre - como o protagonista do filme - em sua vida privada, em sua casa junto da família ou a cavalo em sua propriedade rural, longe do brilho da vida social com os prazeres e conflitos que provoca). 
Notemos que, na entrevista, Gilda começa por marcar uma leve divergência das interpretações sugeridas pelo entrevistador em suas perguntas iniciais, tanto no que concerne ao caráter autobiográfico do filme, quanto no que refere à importância, nele, da questão da política. No que concerne ao primeiro ponto, opõe o caráter essencialmente autobiográfico de um filme como A Morte em Veneza ao filme de Visconti como obra de imaginação (que nem por isso deixa de estar impregnada por temas que se entrelaçam também com a vida do Diretor); no que concerne à dimensão política, insiste no fato de que ela é muito menos presente neste filme do que em filmes anteriores como $\mathrm{La}$ terra trema, Rocco e seus irmãos e 0 Leopardo ${ }^{31}$. 0 essencial é a contraposição entre duas formas de vida: a da família caótica e irregular que invade a intimidade do protagonista e a de sua própria família, ordenada e aristocrática, cristalizada no quadro que pende na parede. Também a relação de simpatia que liga o protagonista à figura do jovem interpretado por Helmut Berger passa pela cumplicidade entre connaisseurs, que são capazes de se entender na discussão da datação e da autoria de um quadro antigo. Nesse entrecruzamento é o tema da morte que emerge, tanto no caso do jovem rebelde como (e sobretudo) da morte antecipada pelo velho colecionador, sem esquecer da morte do mundo social e cultural em que se formou e que constitui a única atmosfera em que pode respirar.

Mas que ligação pode haver entre este filme e Blow-up onde, segundo a declaração explícita de Antonioni, trata-se de festejar o mundo contemporâneo e a expansão, o refinamento da tecnologia que o caracteriza? Não é apenas o tema do artista e sua consciência infeliz ou a do colecionador que permite a passagem do pólo de Mário de Andrade ao pólo do cinema italiano: deixando de lado a conexão evidente com o protagonista de Conversation piece, em Blowup, Thomas junta as fotografias que tira sem cessar, como Mário de Andrade juntava as peças de sua coleção. Como o escritor brasileiro, Thomas também "grafa, fotografa, registra, recolhe". 0 que nos importa todavia, no ensaio sobre Antonioni, é a maneira pela qual aponta para o ponto cego do criador, que se revela nas entrevistas em que o Diretor de Blow-up procura revelar sua intenção e o significado de sua obra (embora ele mesmo confesse: "O meu negócio é contar histórias, narrar com imagens, nada mais", marcando a diferença das funções do artista e do crítico ou do intérprete).

31 Cabe marcar aqui a observação feita por Gilda, na referida entrevista, do caráter "pessoal" de sua interpretação, ligada à natureza quase "apolítica" de sua personalidade. Trata-se de uma pista a ser explorada na parte final deste texto. 
Em todo caso vejamos, a despeito da observação sobre a especificidade do "negócio" do cineasta, como Antonioni interpreta seu filme numa entrevista de 1967:

Em outros filmes tentei examinar a relação entre uma pessoa e outra, com maior freqüência a sua relação amorosa, a fragilidade de seus sentimentos, e tudo o mais. Neste filme nada disso tem importância. Aqui é a relação entre um indivíduo e a realidade - as coisas que estão ao seu redor. Não há história de amor na fita, mesmo que vejamos relações entre homens e mulheres. A experiência do protagonista não é sentimental nem amorosa; antes uma experiência que se refere à sua relação com o mundo, com as coisas que encontra diante de $\mathrm{si}^{32}$. É um fotógrafo. Um dia fotografa duas pessoas num parque. Um elemento da realidade que parece real. E é. Este filme talvez seja como Zen: no momento em que você o explica, você o trai. Ou seja, um filme que pode ser explicado com palavras não é um filme verdadeiro $^{33}$ [Os grifos são de Gilda de Mello e Souza].

Os grifos da ensaísta marcam os pontos essenciais de seu ensaio ou de sua interpretação alternativa do filme. 0 ponto de partida do ensaio é o gigantesco processo de $v i$ sualização do Mundo, operado no albor da modernidade e aprofundado no século XIX: com a ajuda de Lucien Febvre e de Lewis Munford, Gilda descreve o desaparecimento do homem-do-ar-livre guiado pelo olfato e pelo tato como pela audição e pela visão e o advento do homem-de-estufa que multiplica ao infinito o poder e o alcance da visão. Privilégio da visão e das técnicas que culminariam na fotografia e no cinema que, antes de se tornar arte, era apenas uma técnica, como diz Panofsky, que tinha graça por permitir "ver as coisas se mexerem como se fossem reais". Sobre esse pano de fundo, vemos desenhar-se o itinerário de Antonioni, que se demora no gênero do documentário, de 1943 a 1950, quando estréia com o longa-metragem Crimes da Alma (Cronaca di un amore). E a descrição do itinerário culmina na questão crucial: "Em geral os filmes de Antonioni são repetitivos e retomam os mesmos conflitos amorosos, a dificuldade permanente de conciliar carreira e afeição, sucesso profissional e integridade artística. Contudo, a aná-

32 Num estilo que me faz lembrar o "retorno às coisas elas mesmas" da fenomenologia que parece manifestar-se na forma literária do nouveau roman e que, antes dessa geração pós-guerra, já se manifestara na poesia de Francis Ponge, cujos ecos podemos ouvir na obra de João Cabral de Melo Neto. Lembremo-nos que Michel Butor foi o tradutor para o francês do livro Teoria do Campo da Consciência do notável fenomenólogo Aron Gurwitsch, editado em Bruges, pela Desclée de Brouwer em 1957.

33 A idéia e o figurado, p. 156. 
lise dos sentimentos, dominante nas primeiras obras, passa com o correr do tempo para o segundo plano e, à medida que o amor se esgarça, o protagonista tende a substituir a relação intima e corpórea que mantinha com o mundo - como Aldo, o operário, em 0 grito (Il grido) - pela relação mental e quase abstrata que em Blow-up, por exemplo, liga Thomas à sociedade moderna. Por outro lado, se examinarmos como os personagens centrais masculinos se distribuem no elenco das profissões, veremos que eles se afastam, gradativamente, das escolhas tradicionais para aderir às oportunidades oferecidas pela tecnologia do presente. Assim, com a exceção do protagonista de A noite, que é escritor, e representa um pequeno desvio da dominante, eles serão sucessivamente pintor (As amigas), arquiteto (Aventura), engenheiro (Deserto vermelho), corretor de valores (0 eclipse) e por fim fotógrafo (Blow-up). Será que Antonioni quer significar com esta progressão a vitória triunfal da técnica?" ${ }^{34}$.

No começo de sua descrição da curva desenhada pela evolução da filmografia de Antonioni, Gilda parece tender, de início, a responder afirmativamente à pergunta que acabamos de citar. Com efeito, é verdade que a estrutura básica permanece inalterada ao longo de todos os filmes de Antonioni, sempre centrados numa busca invariavelmente ligada a uma morte. Mas tudo se passa como se a exploração dos conflitos entre carreira e afeição, sucesso profissional e integridade artística, evidente nas primeiras obras, fosse progressivamente apagada, permitindo a montagem de uma nova perspectiva que privilegia uma relação técnico-cognitiva com o mundo, que deixa de lado a análise das oscilações dos sentimentos e dos conflitos intra e inter-pessoais. Os personagens centrais deixariam progressivamente de privilegiar a tradição artística e os valores do humanismo para fazer o elogio da tecnologia triunfante da segunda metade do século XX.

Antes de entrar na análise de Blow-up, que é o tema central do ensaio, Gilda descreve essa mudança de óptica, passando brevemente por três filmes anteriores: A aventura, $O$ eclipse e Deserto vermelho. No primeiro desses filmes, na busca de Ana desaparecida, Sandro revela o segredo que o habita: o desencanto ou a tormenta de um arquiteto que não ignora sua nulidade ou sua falta de integridade. É na seqüência da cidade de Nota que o arquiteto exprime a experiência pungente do abismo que separa o esplendor do barroco do que há de trivial e efêmero em sua própria obra: "Que liberdade extraordinária. Era com isso que eu sonhava...". Logo em seguida temos a cena em que a dolorosa descoberta 
se exprime na mutilação da obra de arte, quando Sandro destrói (voluntariamente, mas escondendo a intenção perversa sob a aparência do acidente casual), cobrindo de tinta o esboço do jovem arquiteto que desenhava uma igreja da cidade. Gesto que, nas palavras de Gilda, desmascara "a consciência infeliz e o ressentimento profundo do personagem" 35 . Já com $O$ eclipse e Deserto vermelho a consciência infeliz parece deixar o primeiro plano. $O$ eclipse significaria um grande passo em direção de uma nova figura do cinema: um filme puramente plástico ${ }^{36}$ que deixa a intriga na sua margem, onde perdem peso os dilemas psicológicos, éticos e estéticos dos personagens e, sobretudo, o conflito com o mundo presente, e que "representa uma espécie de distanciamento do figurativo, de namoro com a abstração" 37 . No passo seguinte do itinerário de Antonioni, Deserto vermelho, abre-se mais claramente o espaço que permitirá a eclosão do filme que é nosso télos: Blow-up. É, pelo menos, o que diz enfaticamente Antonioni numa entrevista concedida a Jean-Luc Goddard em novembro de 1964. Gilda escolhe, na entrevista, seus momentos mais significativos: para Antonioni a crise do protagonista desse filme "...é sobretudo uma questão de adaptação: há pessoas que já se adaptaram e outras, como Giuliana, que ainda não o conseguiram [...] Minha intenção não foi a de acusar de desumano o mundo industrial, onde o indivíduo é esmagado e conduzido à neurose, mas, ao contrário, traduzir a beleza desse mundo, onde as fábricas podem ser belas" ${ }^{38}$. Numa palavra: - adeus à consciência infeliz! Sua infelicidade nada mais é do que a cegueira que a impede de ver a beleza do mundo industrial, onde finalmente o Absoluto se revela ao sujeito finito sob a forma da beleza.

Estamos assim no pórtico de Blow-up, filme onde Gilda de Mello e Souza será capaz de diagnosticar o ponto cego da visão (ou do projeto) de Antonioni, que lhe torna inaccessível o sentido de sua própria obra. É certo que há uma mudança de direção na filmografia: o protagonista do filme não é, ou pelo menos está longe de aparentá-lo, uma consciência infeliz. De câmara na mão (essa prótese de seu organismo) duela apenas com o mundo das coisas e o domina, explorando-o cada vez mais precisamente à medida em que se se-

35 Ibidem, p. 157.

36 Como na obra de Godard dos anos 80 "o cinema brinca de pintura", nas palavras de Philipe Dubois em Cinema, Vídeo, Godard, Ed. Cosacnaify, S. Paulo, 2004, p. 251.

37 A idéia e o figurado, p. 154.

38 Ibidem, p. 156. 
guem as ampliações de suas fotos. Sem drama, esse profissional está perfeitamente adaptado ao mundo em que vive, ligado de maneira eficaz com o mercado sempre aberto a seu trabalho (embora não integralmente separado do mundo da arte, na medida da ligação entre fotografia e pintura ou mesmo do "parentesco" entre o fotógrafo Thomas e o pintor Bill $\left.^{39}\right)$. Mas não é certo que Thomas, fascinado pelo mundo dos objetos, não se envolva em relações dramáticas com outras pessoas. Gilda sublinha a dramaticidade extrema da relação entre o fotógrafo e suas modelos, permeada de hostilidade e de erotismo, como transparece em três seqüências. Na primeira, indiferente, o fotógrafo abandona suas modelos, que estão "imobilizadas e de olhos fechados" ${ }^{\text {", }}$, sem que elas percebam, tratando-as, assim, como se fossem coisas. Na segunda, estabelece uma relação conflituosa - sado-masoquista - com as duas meninas que assediam o fotógrafo em busca de prestígio e que terminam por ele assediadas de modo violento. Na terceira, bem mais complexa, a relação do fotógrafo com sua modelo culmina numa alusão à posse amorosa (com Thomas que monta sobre Veruschka) onde se mesclam desprezo e intenção de profanação. Oculta na trama ou nas dobras da narrativa, a meditação sobre as ambigüidades da relação erótica permanece presente, ao contrário das declarações explícitas de Antonioni.

Meditação sobre a ambigüidade e as contradições das relações inter-humanas que está presente no filme, onde ainda uma vez se cruzam amor e crime, como na obra anterior do cineasta. É o que observa Gilda ao dizer: "o avesso do amor é, muitas vezes, o crime”. Aqui está apontado o ponto cego do criador: "Assim, ao contrário do que era afirmado na entrevista, Blow-up se refere insistentemente ao amor, mas para sublinhar sempre o aspecto mecânico, descarnado, frágil, anormal (de voyeurismo) e mesmo criminoso, que ele pode assumir no mundo contemporâneo"41. Do mesmo modo, a perfeita adaptação técnica ao mundo, a multiplicação do poder cognitivo permitido pelo refinamento da técnica fotográfica, parece ser acompanhada por uma cegueira de Thomas, que perdeu completamente o modo de ser do homem-de-ar-livre e só pode ver através das reproduções fotográficas e de suas mil ampliações. Como diz Gilda de Mello e Souza: “Já não enxerga mais o mundo a olho nu, está perdido entre as coisas, esquecido daquela relação íntima com a natureza do homem-de-ar-livre, das crianças,

39 Ibidem, p. 158-9.

40 Ibidem, p .159.

41 Ibidem, p. 162. 
das mulheres, relação espontânea e táctil que o próprio Antonioni rememora com nostalgia na metáfora insistente do contacto do dedo com o objeto: em $A$ aventura, durante a longa espera na ilha, o dedo de Claudia, contornando a folha do arbusto; em Blow-up o dedo que Patrícia desliza, pensativa e infeliz, sobre a corda estendida" ${ }^{" 2}$. Mais ainda, aqui como em toda filmografia anterior, repitamos, o tema central continua sendo o da articulação entre busca e morte. E, ao contrário do elogio da adaptação ao mundo, no filme acabamos por ver o retorno ao tema do abatimento e da derrota, assim como o da fuga pela fantasia.

Esse tema da fuga, que emerge no diálogo entre Thomas e a mocinha do antiquário (Ir para o Nepal? Ou para Marrocos?), está presente na abertura e no fim do filme, com os dois episódios em que irrompem os clowns. Gilda insiste na distância que separa Antonioni de Visconti, com a fuga para o passado e de Fellini, com a fuga para a infância (mas a ligação entre a fantasia e a presença dos palhaços não nos reaproxima, de algum modo, do autor de La Dolce Vita?, como poderíamos perguntar à margem do ensaio "Variações sobre Michelangelo Antonioni"). Mas retornemos, como é preciso, à análise de Blow-up. Na abertura e no final do filme, segundo Gilda, a presença dos palhaços arma uma complexa alegoria. No contacto entre eles e o fotógrafo que, sério, cumpre sua tarefa profissional, cria-se "uma relação cordial, lúdica, um verdadeiro pacto" ${ }^{43}$, que nos leva para longe do propósito declarado de Antonioni. Quanto à aparição dos clowns, no fim do filme, cabe citar nossa autora por extenso: "Ruidosos como sempre, eles reaparecem e cercam a quadra de tênis, onde dois deles iniciam uma partida simulada, fingindo pelos gestos e o movimento do olhar a presença fictícia das raquetes e da bola. Um pouco afastado da cena, Thomas, que acaba de sair do parque, observa com atenção o jogo curioso, interrompido a certo momento como se a bola tivesse sido arremessada na direção do fotógrafo. Os jogadores, parados, interrogam-no com o olhar e, apontando com insistência para a bola, sugerem por gestos que ele a devolva. Thomas hesita, indeciso, e finalmente se curva, apanha a bola invisível e a devolve à quadra. 0 jogo prossegue normalmente, nós ouvimos o ruído das pancadas no chão, vemos o olhar de Thomas ir e vir, acompanhando os lances da partida. Ele então abaixa os olhos, como quem aceitou com humildade as regras do jogo, e a câmara executa um travelling

42 Ibidem, p. 162. É impossível não lembrar aqui a bela frase de Bachelard: "a idade da pedra polida é a idade da pedra acariciada".

43 Ibidem, p. 167. 
para o alto, focalizando-o de cima, numa tomada aérea" ${ }^{4}$. De qualquer maneira, na passagem da primeira para a segunda seqüência, marca-se o desvio em relação à aparente vocação "realista" do filme. Com os clowns passamos da alternativa entre o espaço-da-natureza e do espaço-da-técnica para a busca nostálgica da utopia da "terra sem males" no espaço da fantasia. Como o Nepal e o Marrocos que emergem em Blow-up, numa obsessão permanente, o Quênia aparecia em $O$ eclipse, a Venezuela em $O$ grito e a $\mathrm{Pa}-$ tagônia em Deserto vermelho. Assim, só podemos concluir com Gilda de Mello e Souza que: “Todos esses elementos apontam, paradoxalmente, para uma obra diversa da que ele projetou realizar, demonstrando que a intenção do criador é precária diante da autonomia das formas" ${ }^{45}$. Conclusão que converge com aquela a que tendia a análise crítica nos ensaios consagrados a Mário de Andrade.

IV

Depois de percorrer de maneira perfunctória dois exemplos da atividade exegética de Gilda de Mello e Souza, resta voltar a atenção, como anunciado desde o início deste texto, para os efeitos filosóficos desse trabalho a despeito da "despretensão teórica" 46 que ostentam. E começo endossando uma frase do ensaio já citado de Otília Beatriz Fiori Arantes, que afirma, descrevendo a sinuosidade do procedimento crítico de Gilda: "Pois é nesse vai e vem entre a pintura, sua história e a realidade que se move a nossa autora - utilizando permanentemente e ao mesmo tempo relativizando as lições dos mestres da escola de Warburg". O que interessa é aprofundar o sentido dessa ligação de certo modo ambígua com a referida Escola: que significa aqui relativizar? Para fazê-lo, parece útil comparar os textos "epistemológicos" de Erwin Panofsky com a concepção de arte e da experiência estética a ser desentranhada das entrelinhas dos ensaios de Gilda de Mello e Souza.

Detenhamo-nos, para esse fim, especialmente no curto ensaio de Panofsky "Sobre o problema da descrição e da in-

44 Ibidem, p. 168. Aqui também, creio, seria oportuna uma alusão a Fellini. Essa visão do alto, que nos revela a solidão do fotógrafo não seria simétrica à solidão do protagonista de Oito e meio, quer quando é apresentado, isolado e solitário dentro de seu carro, em meio ao congestionamento, quer quando sobrevoa a praia e é laçado, por seus colegas, para retornar ao quotidiano e à realização de seu filme? Uma solidão que busca a fuga pela fantasia e que tem na parceria com os palhaços uma via privilegiada.

45 Ibidem, p. 170.

46 Cujo aspecto positivo será tematizado adiante. 
terpretação do conteúdo das obras das artes plásticas"47. Ninguém ignora a importância, no método crítico de Panofsky, da passagem da descrição para a interpretação ou da iconografia para a iconologia, das aporias que tal passagem implica e da maneira pela qual o autor procura desembaraçar-se delas. Para começar, lembremos o esquema ternário presente em toda a obra e exposto esquematicamente no ensaio (que nesta edição lhe acrescenta o quadro dos três níveis, que nos levam da descrição à interpretação, presente em outro texto, no livro Ensaios de Iconologia ${ }^{48}$ ).

No primeiro nível, como nos seguintes, temos uma estrutura composta de três instâncias, a saber: Objeto de interpretação, que consiste no seu sentido fenomênico, que por sua vez apresenta tanto a face do sentido "objetivo", quanto a face do "sentido expressivo"; Fonte subjetiva da interpretação, que consiste na experiência existencial ou vital do sujeito percipiente; Corretivo objetivo da interpretação, que consiste na História das configurações (ou na suma das possibilidades de representação [Darstellung] artística). No segundo nível, mais elevado, temos uma trindade mais complexa: Objeto de interpretação, que consiste no sentido semântico; Fonte subjetiva de interpretação que consiste no conhecimento literário; Corretivo objetivo da interpretação que consiste na História dos tipos (suma das possibilidades de representação [Vorstellung] artística). Finalmente, no terceiro nível, o mais elevado do progresso interpretativo: Objeto de interpretação, que consiste no sentido documental; Fonte subjetiva de interpretação, que consiste no comportamento decorrente de uma "visão do mundo" [Weltanschauung]; Corretivo objetivo da interpretação, que consiste na História geral das Idéias (suma das possibilidades de visão do mundo).

0 leitor há de notar que, em cada nível, a fonte subjetiva da percepção encontra-se situada entre seu objeto e o corretivo que lhe permite modificar o sentido da primeira figura apresentada pelo objeto. Mais do que isso, ao passar do nível um ao nível dois, esse efeito retroativo se repete: o corretivo tipológico não altera apenas o sentido semântico, mas retroage sobre o sentido fenomênico. E, mais ainda, no último nível, o corretivo que passa pela História Geral da Idéias, revelando o sentido documental depois de levar o sujeito à consciência da ligação do comportamento (ou do estilo de existência) a uma Weltanschauung, também retroage

47 Cf. A Pintura, textos essenciais, Vol. 8, Descrição e Interpretação, Direção geral de Jacqueline Lichenstein e Apresentação de Jean-François Groulier, Ed. 34, S. Paulo, 2005.

48 Ibidem, p. 85. 
sobre os níveis anteriores, fechando uma espécie de círculo ao dar a última e complexa forma ao raso sentido fenomênico de que partimos (ou de que parte sempre a percepção espontânea). 0 aprofundamento progressivo da análise, que passa da iconografia para a iconologia, acaba por revelar o seu caráter circular. Eis a aporia a ser dissolvida: essa circularidade não seria viciosa, implicando um petitio principii? É claro que, em cada um dos níveis, a instância corretiva visa neutralizar a pura projeção dos pré-juizos subjetivos. 0 que não impede que, na sua totalidade, o movimento interpretativo permaneça circular em sua essência ${ }^{49}$.

Em seu artigo de 1933, Panofsky tem fresca na memória a lembrança da polêmica entre Heidegger e Cassirer (seu amigo, que também passou pela Escola de Warburg) e é obrigado a distanciar a idéia da forma necessariamente circular da interpretação da circularidade da hermenêutica do autor de Ser e Tempo ${ }^{50}$. Esse é o tema da quarta e última parte de seu artigo sobre descrição e interpretação: Panofsky começa por citar o trecho de Kant e o Problema da Metafísica, onde afirma que é preciso ultrapassar a superfície do texto (não limitar-se a repeti-lo ou glosá-lo), que é necessário ir "além da formulação textual, [tornar visível - B.P. Jr.] o que Kant procurou trazer à luz com a sua fundamentação; mas isto, Kant não foi capaz de dizê-lo (...). É claro que toda interpretação precisa necessariamente fazer uso da força para arrancar do que as palavras dizem o que elas querem dizer"51. Sem negar a necessidade desse uso da força, Panofsky busca dar-lhe um sentido diferente do heideggeriano ${ }^{52}$. Assim, no caso de Kant, nosso autor recorre, sem citá-lo, a Cassirer. Faltaria a Heidegger a instância corretiva que "já está dada na facticidade histórica", que nos impede de forçar o texto, o limite (a separação entre formas históricas diferentes de pensamento) que proíbe a projeção retrospectiva de categorias ausentes no passado. Projeção retrospectiva que seríamos tentados fazer, por exemplo, lendo

49 De resto, nada há de escandaloso nessa circularidade e ela não nos mergulha no abismo do subjetivismo ou do relativismo. Não reconhecemos, com efeito, uma circularidade semelhante na própria ciência, quando aceitamos, como é razoável, como boa parte da epistemologia contemporânea, a "impregnação teórica dos enunciados observacionais" ou o caráter "holístico" das teorias científicas?

50 Heidegger insiste no caráter virtuoso e não vicioso do círculo hermenêutico, no qual deveríamos entrar, em lugar de tentar dele sair.

51 A Pintura, Textos essenciais, p.101.

52 Ibidem, p. 103, onde uma referência a Edgar Wind permite-lhe dar nova versão ao círculo hermenêutico que afasta o perigo do arbítrio interpretativo em que Heidegger parece mergulhar. 
o "tédio da vida moderna" na Melancolia de Dürer. Ao contrário do que “... o historiador da filosofia podia aprender com a história das idéias do século XVIII sobre os limites a que está restrita uma exegese ontológica de Kant, contanto que ela não queira renunciar aos direitos - e aos deveres de uma 'interpretação" "53.

Ao introduzir a questão nestes termos, não o faço com a intenção de situar Gilda de Mello e Souza em um dos extremos desse debate, cuja origem está na polêmica entre Heidegger e Cassirer em Davos (1929). Nossa autora não parece cuidar muito dos problemas e das alternativas de ontologia fundamental ou da tentativa de fundar a análise da obra de arte numa epistemologia das Geisteswissenschaften que remete à crítica kantiana. Advirto o leitor que se endossei o enunciado de Otília sobre a "relativização" das teses da Escola de Warburg, não pensava de modo algum na projeção retrospectiva da ontologia de Heidegger na interpretação da "história do Ser" (que não deixa de ser uma forma de relativização do passado por obra de uma óptica seletiva muito particular). De qualquer maneira, Gilda está mais próxima de Panofsky do que de Heidegger. Sem dúvida a insistência na "precariedade do criador" é a mesma para nossa autora e para Panofsky. Trata-se de tema constante nos escritos do membro da Escola de Warburg, como insiste Pierre Bourdieu no posfácio que acrescentou à tradução que fez para o francês do livro Arquitetura gótica e pensamento escolástico, privilegiando, nesse capítulo da história da arte, a idéia de uma "intenção objetiva" que nada tem a ver com a intenção subjetiva do criador (Bourdieu investe contra os teóricos da Kunstwollen ${ }^{54}$ ). Para além da intenção do artista, o que é objeto de trabalho dos dois autores, o alemão e a brasileira, são os códigos, os tipos, os sistemas de sinais e significações, as "gramáticas". Numa palavra, tanto num caso como no outro temos obras primas de iconologia. Mas uma iconologia praticada segundo espíritos diferentes: para um, a iconologia se baseia essencialmente numa epistemologia - em parte aquela de Cassirer, com sua direção iluminista e universalista, que se prolonga numa "Filosofia das formas simbólicas", em que a ordenação artística da experiência e do mundo abre o espaço de uma estruturação simbólica superior, que é fornecida pela ciência. Como na Fenomenologia de Hegel, para Cassirer (aqui bem pouco neo-kantiano) mito, linguagem, reli-

53 Ibidem, p. 108.

54 Aparentemente a contrapelo de Panofsky, que dá a impressão de não se voltar abertamente contra seu mestre Riegl, criador do referido conceito. 
gião, arte e ciência se sucedem como formas do espírito que tendem à universalidade da Razão. Tendência que Pierre Bourdieu leva ao limite, introduzindo na obra de Panofsky mais do que um "grão" do "estruturalismo" então em moda na França, chegando mesmo ao exagero de aproximá-la da gramática generativa e transformacional de Chomsky. Não seria melhor ligá-la à "gramática" de Wittgenstein, em tudo oposta à gramática generativa e transformacional, por sua recusa de reduzi-la à uma forma lógica ou a um cálculo, por dar-lhe uma dimensão mais pragmática do que sintática ou semântica (por sua ênfase na dimensão do uso como campo do sentido), e sobretudo por fazer dela um instrumento de ampliação do campo de visão, escada que permite chegar à Übersicht (visão de sobrevôo ou, simplesmente, visão geral?). Ligando a empresa de Panofsky à de Saussure, Bourdieu nos diz no último parágrafo de seu Posfácio: "Erwin Panofsky mostra aqui de forma brilhante que só pode fazer o que faz sob a condição de saber a cada momento o que faz, pois as operações, tanto as mais humildes como as mais nobres, da ciência valem o que vale a consciência teórica e epistemológica que acompanha essas operações”. É bem essa aproximação entre a análise das obras de arte e os métodos das hard sciences que jamais encontraremos na obra de Gilda. Aliás, se não estou redondamente enganado, é o que ela mesma diz obliquamente contra essa tendência no texto seguinte, da nota 6 de seu ensaio sobre Antonioni: "É curioso que o método adotado por Thomas, no estúdio, se aproxima daquele que, segundo Moles, a teoria da informação gostaria de propor aos filósofos como síntese de uma atitude estruturalista e uma atitude estética. Levando em conta que 'perceber é perceber formas' a teoria da informação proporia decompor o retrato do universo em pedaços de conhecimento, visando, primeiro, fazer o levantamento de um repertório e, em seguida, recompor um modelo, que seria o simulacro desse universo, aplicando nessa tarefa as regras de assemblage ou interdição". Numa palavra, uma estética construída da perspectiva de um olhar mecânico.

$\mathrm{Na}$ verdade, estamos diante de um duplo problema: 1) como é possível fazer um uso tão rico de tradições críticas como a da escola de Warburg, sem comprometer-se com a abstração das filosofias e epistemologias a que estão ligadas?; 2) como é possível aclimatar as boas tradições da Estética européia no contexto brasileiro, sem trair, ao mesmo tempo, a teoria de origem e o novo campo de aplicação? Na verdade, não é possivel responder a essas duas questões separadamente, sem transitar, com todo o vagar 
possível, entre elas. A obra crítica de Gilda deriva da convergência entre o movimento de modernização da literatura brasileira e os esforços teóricos dos sociólogos e dos historiadores para dar conta da formação brasileira. Mais do que isso, nesse contexto de verdadeira revolução intelectual, a reflexão estética volta-se para o futuro, ao contrário da óptica européia que assume espontaneamente o peso da tradição, exceto nos pequenos grupos de vanguarda que desencadeiam seus movimentos fora da Universidade e que pouco cuidam do passado ou da arqueologia das Artes. Essa característica da óptica européia é visível mesmo nas polêmicas mais vivas do presente, como a que se exprimiu nos movimentos "zurück Kant" (desde a segunda metade do século XIX até o século XX, em sucessivas ondas) que está na origem dos modelos europeus da história da arte e da reflexão estética de que Gilda lança mão com a maior liberdade. Repitamos três frases de nossa autora, já citadas no início deste texto, descrevendo o itinerário de sua geração: "As conquistas eram em geral provisórias e não se apoiavam na segurança racional dos sistemas. Mas aquele momento de transição entre o sonho das vanguardas e a chegada vitoriosa dos especialistas, delineavam à nossa frente um recorte novo da realidade. Talvez uma invenção da realidade, tal como de tempos em tempos a arte efetua, para renovar o sentimento da divindade, do homem ou, mais modestamente, da paisagem". 0 caráter essencialmente prospectivo aí revelado é essencial, na necessidade que implica de inventar a realidade e que aproxima a tarefa cognitiva mais da própria arte do que da ciência (que deveria vir depois). Caráter que será tanto mais visivel quando contraposto às dificuldades face aos movimentos de renovação ou de criação com que se defronta Pierre Bourdieu que, na ocasião, faz sua a teoria de Panofsky, no Posfácio já ci$\operatorname{tado}^{55}$. Situada na periferia do capitalismo, não poderia ser outro o itinerário de Gilda, nossa mestra de Estética.

Mais ainda: não é necessário referir-se à situação brasileira para compreender que uma obra de pensamento não se demore na edificação de uma Teoria. Nas tradições rivais da fenomenologia e da filosofia analítica podemos encontrar exemplos de filósofos não fundacionistas que recusam o modelo "intelectualista" do pensamento ou a concepção da filosofia como uma espécie de Ciência Superior. Penso em autores como Wittgenstein e Merleau-Ponty - que jamais se comunicaram ou se influenciaram reciprocamente - em cujas obras é possível vislumbrar uma mesma con-

55 Como em sua própria teoria faz sua a categoria de habitus no sentido que lhe foi atribuído por Panofsky. 
cepção da filosofia que privilegia a dimensão do acesso originário pré-científico ${ }^{56}$ ao mundo, onde a visão ${ }^{57}$ ganha novamente a importância que perdera desde Platão. Ou ainda em Bachelard que, passando da reflexão epistemológica a uma espécie de "fenomenologia" da imaginação, acaba por dar à última a função de raiz da totalidade da Filosofia. Numa palavra, filosofias onde a Arte e a Estética se mostram como forma privilegiada de acesso ao próprio coração da Filosofia.

Com esses elementos, podemos esboçar o que poderíamos chamar de hermenêtica de Gilda de Mello e Souza. Nela, é claro, é reconhecida a circularidade da interpretação, mesmo na forma mais evidente da projeção de escolhas do intérprete, como é reconhecido na entrevista sobre Conversation piece, no uso da expressão "interpretação pessoal". Como também é reconhecida na expressão inventar a realidade, do texto citado há pouco e que já servira de ponto de partida deste ensaio. Mas, é claro, não se trata de algo como um "teste projetivo", onde a obra interpretada funciona como um espelho onde o intérprete só é capaz de ver a si mesmo e suas próprias escolhas. Pois o projeto interpretativo não só mobiliza instâncias ou instrumentos "corretivos" (à maneira dos hermeneutas em geral e de Panofsky

56 No caso de Wittgenstein, o plano secundário da epistemologia é acompanhado por um olhar sobranceiro lançado sobre a ciência, como é visível na seguinte frase que manifesta a expectativa, como que um desejo da "Zerstörung eines grässlichen Übels, der ekelhaften, seifenwässringen Wissenschaf (manuscrito. 131, de 19/VIII/1946, incluido nas Vermichte Bemerkungen); traduzindo: “...destruição desse mal horrivel, dessa lavagem nauseabunda que é a ciência". Ou numa outra, em que reformula a famosa expressão de Goethe nos seguintes termos: “Die Weiseheit ist grau.,'Das Leben aber und die Religion sind farbenreiche (manuscrito 134, de 27/VI/1947, incluído nas Vermichte Bemerkungen"); traduzindo: “ ‘A sabedoria [no sentido de saber teórico, ciência - nota de B. P. Jr] é cinza'. Mas a vida e a religião são ricas de cores". É preciso sublinhar que o conceito de religião, para Wittgenstein, está indissociavelmente ligado aos conceitos de estética e de ética: tais conceitos formam um todo indissociável, ao contrário do que ocorre na filosofia de Kierkegaard, que distingue os níveis da estética, da ética e da religião, que sucedem em ritmo ascencional. No caso de Merleau-Ponty, é desnecessário sublinhar sua insistência sobre a prioridade da percepção sobre as hipóteses e os modelos construídos pela ciência. Lembremos a primeira frase do ensaio " 0 olho e o Espírito" onde, para contrastar ciência e percepção estética, diz: "A ciência manipula as coisas e renuncia a habitá-las." Ou, mais positivamente, as seguintes frases: "Assim, a pintura nos reconduzia à visão das próprias coisas. Inversamente, como que por uma troca de favores, uma filosofia da percepção que queira reaprender a ver o mundo restituirá à pintura e às artes em geral seu lugar verdadeiro, sua verdadeira dignidade e nos predisporá a aceitá-las em sua pureza" (Cf. M. M.-Ponty, Conversas - 1948, Ed. Martins Fontes, São Paulo, 2004, p. 56).

57 A visão propriamente dita, isto é, a visão do mundo sensível, não sua sublimação como nóesis, visão intelectual da essência. 
em particular), como ele tem um caráter polêmico ou subversivo: interpretar, aqui, é convidar a ver de modo diferente. Mesmo no ambicioso projeto husserliano de instituir a filosofia como Strenge Wissenschaft (como ciência rigorosa) não era a "variação imaginária" um momento necessário da redução fenomenológica, dando acesso ao domínio "celeste" das essências? De qualquer maneira, mesmo sem fenomenologia ou sem qualquer outra forma de übris, é preciso reconhecer o valor cognitivo da imaginação, sem a qual não poderíamos modificar nosso modo de ver (pensemos no "ver como" de Wittgenstein) e permaneceríamos prisioneiros de nossos idolos, de nossos preconceitos pessoais ou da tradição passiva e inconscientemente assimilada. Imaginar, aqui, não é o contrário de investigar o mundo objetivo: é abrir-se para o que, até agora, permaneceu invisível. Sem a imaginação ou a variação sistemática do modo de ver, não poderíamos topar com e descobrir os indícios que podem levar-nos ao código iluminador da obra em sua singularidade (assim como descobrir ou ver de modo diverso o próprio código a partir da obra singular). Sem saper vedere não poderemos, mesmo fora das artes plásticas e da Estética, saper leggere e saper ascoltare, isto é, re-ver nossa experiência quotidiana, nossa relação com a sociedade, com a cultura e com o mundo. Noutras palavras, estaremos condenados a permanecer aquém da Filosofia.

Era bem esse lugar central da Estética na Filosofia que deslumbrados descobríamos em 1956, nas aulas de Gilda de Mello e Souza, que tanto nos marcaram.

Janeiro de 2006 